\title{
Economic Fundamental Resilience of Emerging Market Muslim Countries: Is It Enabled To Predict ARDL Panels?
}

\author{
Rusiadi $^{{ }^{*}}$, Ade Novalina ${ }^{2}$, Anwar Sanusi ${ }^{3}$ \\ \{rusiadi@dosen.pancabudi.ac.id ${ }^{1 *}$, adenovalina@gmail.com², anwarsanusi@gmail.com ${ }^{3}$ \} \\ 1,2, Universitas Pembangunan Panca Budi, Medan, Indonesia \\ *rusiadi@dosen.pancabudi.ac.id
}

\begin{abstract}
The research aims to discuss the issue of fundamental economic resilience of Emerging Market's Muslim economies in the long term. Data analysis using ARDL Panel Research results concluded in panel turns the amount of money supply to leading indicators for the control of Indonesia, Bangladesh, Malaysia, Pakistan, and UAE, Saudi Arabia, Turkey. Its position is stable in the short-run and long run. The leading indicator of the effectiveness of variables in the control of the fundamental resilience of Muslim emerging market countries is the investment seen from the stability of short-run and longrun, where the amount of money supply significantly controls Economic durability fundamentals.
\end{abstract}

Keywords: ARDL Panel, Fundamental durability economy, exchange rate, GDP

\section{Introduction}

The fundamental economic lozenges measured from Kokoro's strong macroeconomic variables are affected by internal factors and external factors. Economic fundamentals can be measured by inflation, exchange rates, and the acceptance of trade balance [1,2,3]. Literature that often occurs about economic fundamentals is the first appropriate measure in determining the fundamental economic indicators which are most capable of representing the early detection of a country's fundamental economic weakening [4]. One cause of the impact of declining economic fundamentals is detected by the delay effect of economic conditions. Flowers can affect the occurrence of a delay effect [5]. Hasibuan [6] interest rates as a fundamental economic price. Hai [7] mentions the exchange rate as a strong indicator of the fundamental Lemhanas. Oliner [8] concluded the reserves of DHE and Stock [4], Wimanda [9] Economic growth, net exports, and investments. While the financial services are expressed as the economic Lemhanas price of a country [10]. Emerging markets, especially Mulsim countries have a role in repenting in moving the economy. Research literary phenomena are seen from the following GDP: 

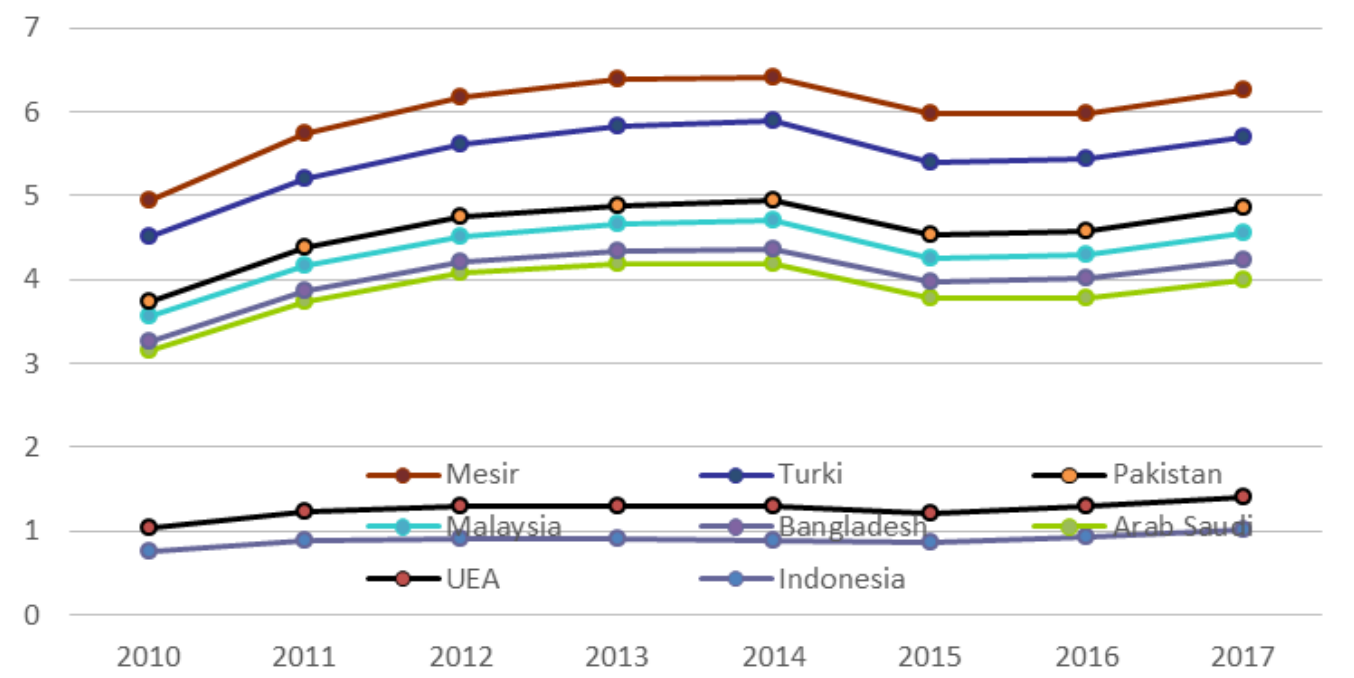

Fig 1. GDP (Billion US\$) Negara Emerging Market Muslim

The decline of Turkish GDP growth, Malaysia, Indonesia occurred in 2015, Turkey's GDP growth dropped to 859.79 billion US \$ from 934.18 billion US \$ previous year, Malaysia dropped to 296.43 billion US \$ from 338.06 US \$ previous year, and Indonesia dropped to 861.85 billion US $\$$ from 890.81 billion US $\$$ the previous year. Decreased economic resilience by the government spending factor, investment, and inflation [11]. To improve economic resilience, the export performance of exchange rate stability and non-traditional market expansion is required, including the improvement of commodity export structures [12].

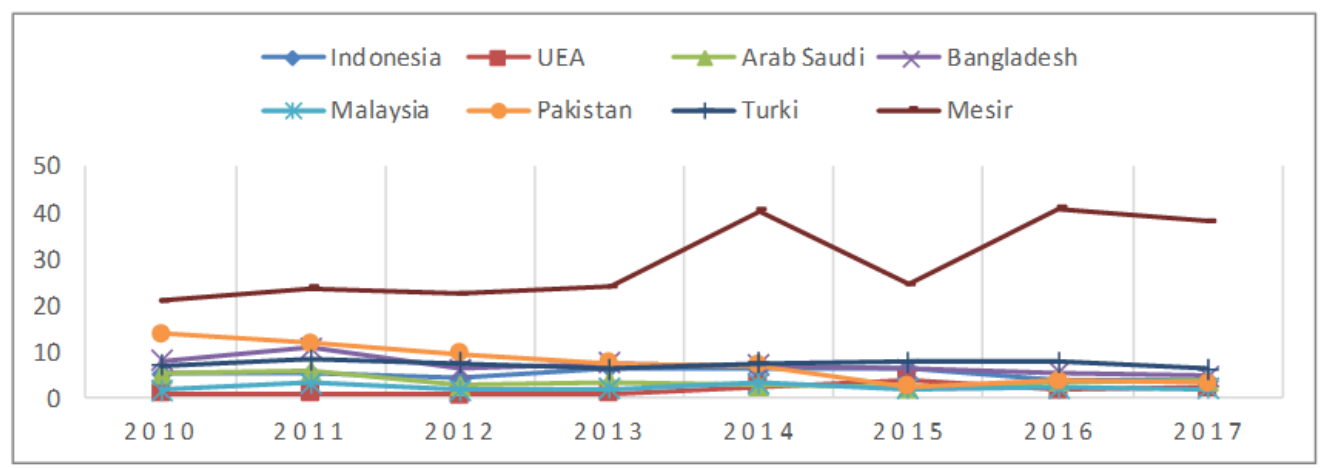

Fig 2. Muslim emerging market inflation

The risk of Muslim state inflation Emerging market, Indonesia's inflation rose to $5.36 \%$ from $5.13 \%$ the previous year, Saudi Arabia rose to $5.83 \%$ from $5.34 \%$ the previous year, Bangladesh rose to $11.40 \%$ from $8.13 \%$ the previous year, Malaysia rose to $3.17 \%$ From $1.62 \%$ the previous year, and Egypt rose to $23.7 \%$ from $20.9 \%$ the previous year. In lowincome countries, the inflation Momentum (quarterly adjusted quarterly rate is declared at an annual level) dropped dramatically over the past year, from an average of 14 percent in 2011 to the current down of 1.6 percent in All three months until September 2012 before starting the trend of ascension in the last quarter of 2012. The sharp decline reflects the combined effect of 
stabilizing the local food prices after 2011 years of drought-related price increases, tightening policies, and easing fuel supply and food disruptions during episodes of political turmoil in the Middle East and parts of the African Sub-Saharan. Sheefeni [13] said that rising flowers impact inflation and economic decline. Sitaresmi [14] Interest rate pathways pursue a policy target of inflation. The tightening of the flowers protects the price volatility of Hussain [15], Hsing [16], and Shenglin [17]. Monetary policy must facilitate investments through appropriate interest rates, exchange, and currency mechanisms $[2,13,18]$.

Fundamental resilience can be seen from the open economic theories by identifying macroeconomic variables, interest, investments, and trading balance such as net exports, foreign exchange reserves, and exchange rates.

\section{The policy of pure discretionary and Rules in open economic fundamentals}

Balance analysis begins with the results of a purely discretionary policy or a discretionary policy. Policymakers define monetary and fiscal policies by minimizing equations (1.3), i.e., Phase 3. The minimization is obtained by FOC equations (1.3) against monetary and fiscal targets $[\mathrm{mP}$ and $\mathrm{gP}]$ and random variables $\mathrm{v}, \omega, \theta$. Susbtitular equations $(1.4 \mathrm{~A})$ and $(1.4 \mathrm{~B})$ to the equation (1.3) to calculate the control of the instruments of the perfect policy, namely:

$$
\begin{aligned}
& E_{\omega, \theta}(L)=E_{\omega, \theta}\left(\frac{1}{1+\alpha}\left[\omega m^{P}+\theta g^{P}-\alpha E(\pi)+v\right]\right)^{2}+ \\
& E_{\omega, \theta}\left(\frac{\alpha}{1+\alpha} \beta\left[\omega m^{p}+\theta g^{P}-E(\pi)+v\right]-\alpha \beta y_{T}\right)^{2}
\end{aligned}
$$

FOC equation (1.5) against the MP and GP with the operator expectations $\omega$ and $\theta$ will produce the following equation:

$$
\begin{aligned}
& {\left[\omega m^{P}+\theta g^{P}-\alpha E(\pi)+v\right]=-\alpha^{2} \beta\left[\omega m^{P}+\theta g^{P}-E(\pi)+v\right]+\alpha \beta y_{T}} \\
& \left(1+\alpha^{2} \beta\right) m^{P}+\left(1+\alpha^{2} \beta\right)\left(1+\sigma_{\omega}^{2}\right) g^{P}=\alpha \beta y_{T}+\left(\alpha^{2} \beta+\alpha\right) E(\pi)-\left(1+\alpha^{2} \beta\right) v
\end{aligned}
$$

$\left[\omega m^{P}+\theta g^{P}-\alpha E(\pi)+v\right]=-\alpha^{2} \beta\left[\omega m^{P}+\theta g^{P}-E(\pi)+v\right]+\alpha \beta y_{T}$

$$
\left(1+\alpha^{2} \beta\right)\left(1+\sigma_{\theta}^{2}\right) m^{P}+\left(1+\alpha^{2} \beta\right) g^{P}=\alpha \beta y_{T}+\left(\alpha^{2} \beta+\alpha\right) E(\pi)-\left(1+\alpha^{2} \beta\right) v
$$

The $\mathrm{mP}$ and GP solutions are obtained by substituted equations (1.6 A) to (1.6 B) or by application of the Cramer determinant method, namely:

$$
\begin{aligned}
& m^{P}=\left[\frac{\alpha \beta(1+\alpha) y_{T}+\left(\alpha^{2} \beta-\alpha\right) E(\pi)-\left(1+\alpha^{2} \beta\right) v}{\left(1+\alpha^{2} \beta\right)\left(\sigma_{\omega}^{2}+\sigma_{\theta}^{2}+\sigma_{\omega}^{2} \sigma_{\theta}^{2}\right)}\right] \sigma_{\theta}^{2} \\
& g^{P}=\left[\frac{\alpha \beta(1+\alpha) y_{T}+\left(\alpha^{2} \beta-\alpha\right) E(\pi)-\left(1+\alpha^{2} \beta\right) v}{(1+\alpha \beta)\left(\sigma_{\omega}^{2}+\sigma_{\theta}^{2}+\sigma_{\omega}^{2} \sigma_{\theta}^{2}\right)}\right] \sigma_{\omega}^{2}
\end{aligned}
$$

The immaturity (1.7 A) and (1.7 B) explains the policy-making REACTION FUNCTION on the demand and aggregate shock and inflation expectations. At stage 1, uncertainty over v, $\omega$ and $\theta$ resulted in inflation expectations being: 


$$
\begin{aligned}
& E(\pi)=E_{\omega, \theta, \nu}\left[m^{P}+g^{P}\right]=E_{\omega, \theta, v}\left[\omega m^{P}+\theta g^{P}\right] \\
& E(\pi)_{D I S}=\frac{\alpha \beta(1+\alpha) y_{T}}{(1+\alpha)+\left(1+\alpha^{2} \beta\right)\left[\frac{\sigma_{\omega}^{2} \sigma_{\theta}^{2}}{\sigma_{\omega}^{2}+\sigma_{\theta}^{2}}\right]}
\end{aligned}
$$

From the equation (1.8), it is known that the uncertainty of fiscal policy instruments $\left[\sigma^{2} \theta\right.$ Height] and the uncertainty of monetary policy instruments $\left[\sigma^{2}{ }_{\omega}\right.$ high] will increase inflation expectations. Substitution of equations $(1.8)$ to $(1.7 \mathrm{~A})$ and $(1.7 \mathrm{~B})$ will result in an optimal fiscal and monetary policy with a purely discretionary policy. The pure discretionary policy explains that the target fiscal policy $[\mathrm{gP}]$ and the target monetary policy $[\mathrm{mP}]$ are optimal on:

$$
\begin{aligned}
& m_{D I S}^{P}=\left[A-A^{T} v\right] \sigma_{\theta}^{2} \\
& g_{D I S}^{P}=\left[A-A^{T} v\right] \sigma_{\omega}^{2}
\end{aligned}
$$

Description:

$$
\begin{aligned}
A & =\frac{\alpha \beta(1+\alpha) y_{T}}{(1+\alpha)\left(\sigma_{\omega}^{2}+\sigma_{\theta}^{2}\right)+\left(1+\alpha^{2} \beta\right)\left(\sigma_{\omega}^{2} \sigma_{\theta}^{2}\right)} \\
A^{T} & =\frac{1}{\left(\sigma_{\omega}^{2}+\sigma_{\theta}^{2}+\sigma_{\omega}^{2} \sigma_{\theta}^{2}\right)}
\end{aligned}
$$

Equations (1.9 A) and (1.9 B) explain that the optimal fiscal and monetary policy at a purely discretionary rate is determined by the shock of the aggregate demand and offer. Bidding surprises and positivity aggregate demand will lower monetary and fiscal policy targets, rather the shock of bidding and negative aggregate demand will increase monetary and fiscal policy targets.

The first component of the optimal fiscal and monetary policy is the A [non-contingent] constant and the slope of the Phillips $[\alpha]$. Curve. The combination of request shock and aggregate bidding $[\mathrm{V}]$ is the stabilization component of each policy instrument. This means that the summation of fiscal and monetary policy stabilization components is the total proportion of bid surprises and aggregate demand. Therefore the shock of the aggregate demand and supply will decrease if the instrument's uncertainty of monetary and fiscal policy rises.

Expectations of inflation, money stocks growth, and government expenditure are determined by the precision of the combination of fiscal and monetary policy control $\left[\sigma^{2} \omega\right.$, $\sigma^{2} \theta$ ]. Therefore, the increased uncertainty of policy instruments will reduce the use of a combination of fiscal and monetary policy. Monetary policy instruments can be controlled perfectly $\left[\sigma_{\omega}^{2}=0\right]$. Then all policies will be controlled with monetary instruments $[\mathrm{gP}=0]$, conversely if fiscal policy instruments can be controlled perfectly $\left[\sigma^{2} \theta=0\right]$ Then all policies will be controlled with the fiscal instrument $\left[\mathrm{m}^{\mathrm{P}}=0\right]$. Therefore, uncertainty determines the activism and the composition of the combination of fiscal and monetary policy instruments.

The difference between the rule and the pure discretionary is crucial, where the rule policy is the determination of the policy before inflation expectations are determined. Therefore the type of rule policy is that policy adjustments affect expectations. Fiscal and 
monetary policy rules are $\mathrm{GP}=\mathrm{G}, \mathrm{mP}=\mathrm{M}$ and $\sigma_{\theta}^{2}=\sigma^{2}{ }_{\omega}=0$. When the rule policy is applied, then the equation (1.8) is changed to $\mathrm{E}(\pi)=\mathrm{M}+\mathrm{G}$. From the equation (1.8) obtained:

$$
E(\pi)_{R U L}=\frac{\alpha \beta(1+\alpha) y_{T}}{(1+\alpha)+\left(1+\alpha^{2} \beta\right)\left[\frac{\sigma_{\omega}^{2} \sigma_{\theta}^{2}}{\sigma_{\omega}^{2}+\sigma_{\theta}^{2}}\right]}=\alpha \beta y_{T}
$$

This means that inflation expectations depend on the Phillips $[\alpha]$ curve slope and policymaker preferences $[\beta]$ so that $\mathrm{E}(\pi)_{\text {DIS }}>\mathrm{E}(\pi)_{\text {RUL. }}$. UL. Minimization of expectations of losses against $\mathrm{M}$ and $\mathrm{G}$ results in the optimal fiscal and monetary policy at the condition $\mathrm{M}=$ $\mathrm{G}=0$. This implies that $\left[m_{R}^{P}=0\right]$ and $\left[g_{R}^{P}=0\right]$ or expectations of the inflation rate at the discretionary policy are always higher than the rule policy. The difference in inflation expectations at the discretionary policy with rule policies is the inflationary bias so that the equation (1.8) can be defined as the inflationary bias of the discretionary policy. The combination of the surprising demand and aggregate offerings in the rule policy is fully transformed into aggregate output and the inflation rate, so the inflationary bias is zero in the rule policy.

\section{Research Method}

The ARDL panel Model is used in predicting the fundamental economy in the face of internal and external economic conditions of a country. An auto-reblock Distributed Lag (ARDL) Pesaran. The ARDL panel techniques test statistics that can compare with two critical values are asymptotic with the formula:

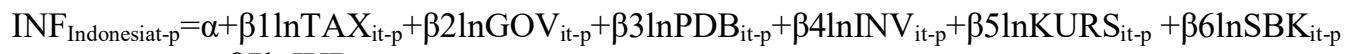

$$
\begin{aligned}
& +\beta 7 \ln J \mathrm{UB}_{\mathrm{it}-\mathrm{p}}+\mathrm{e} \\
& I N F_{\text {Bangladesht-p }}=\alpha+\beta 1 \operatorname{lnTAX} X_{\text {it-p }}+\beta 2 \operatorname{lnGOV} V_{\text {it-p }}+\beta 3 \ln P D B_{\text {it-p }}+\beta 4 \ln I N V_{\text {it-p }}+\beta 5 \operatorname{lnKURS_{it-p}}+\beta 6 \operatorname{lnSBK} K_{\text {it-p }} \\
& +\beta 7 \ln J \mathrm{UB}_{\mathrm{it}-\mathrm{p}}+\mathrm{e}
\end{aligned}
$$

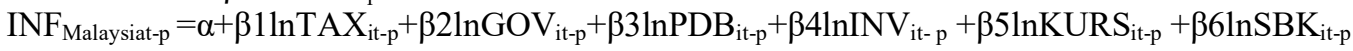

$$
\begin{aligned}
& +\beta 7 \ln J \mathrm{UB}_{\text {it-p }}+\mathrm{e}
\end{aligned}
$$

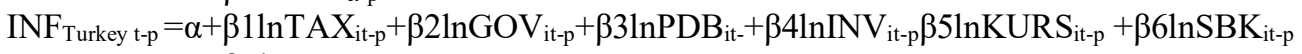

$$
\begin{aligned}
& +\beta 7 \ln J \mathrm{UB}_{\mathrm{it}-\mathrm{p}}+\mathrm{e} \\
& I N F_{\text {UEA t-p }}=\alpha+\beta 1 \operatorname{lnTAX} X_{\text {it-p }}+\beta 2 \operatorname{lnGOV} \text { it-p }+\beta 3 \operatorname{lnPDB} B_{\text {it }}+\beta 4 \operatorname{lnINV} V_{\text {it-p }}+\beta 5 \operatorname{lnKURS} S_{\text {it-p }}+\beta 6 \operatorname{lnSBK} K_{\text {it-p }} \\
& +\beta 7 \ln J \mathrm{UB}_{\text {it-p }}+\mathrm{e} \\
& \mathrm{INF}_{\text {Saudi Arabia t-p }}=\alpha+\beta 1 \ln \mathrm{TAX} \mathrm{X}_{\mathrm{it}-\mathrm{p}}+\beta 2 \ln \mathrm{GOV}_{\text {it-p }}+\beta 3 \ln P D B_{\text {it-p }}+\beta 4 \ln I N V_{\text {it-p }}+\beta 5 \ln K U R S_{\text {it-p }} \\
& +\beta 6 \operatorname{lnSBK} \mathrm{Kit}_{\mathrm{p}}+\beta 7 \ln J \mathrm{UB}_{\mathrm{it}-\mathrm{p}}+\mathrm{e} \\
& \mathrm{INF}_{\text {Bangladesh t } \mathrm{p}}=\alpha+\beta 1 \ln T A X_{\text {it-p }}+\beta 2 \operatorname{lnGOV}{ }_{\text {it-p }}+\beta 3 \ln P D B_{\text {it-p }}+\beta 4 \operatorname{lnINV_{it-p}}+\beta 5 \operatorname{lnKURS_{it-p}}+\beta 6 \operatorname{lnSBK} K_{\text {it-p }} \\
& +\beta 7 \operatorname{lnJUB} \mathrm{B}_{\mathrm{it}-\mathrm{p}}+\mathrm{e}
\end{aligned}
$$

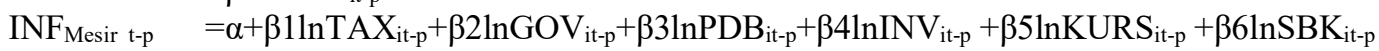

$$
\begin{aligned}
& +\beta 7 \operatorname{lnJUB} \mathrm{Bt}_{\mathrm{it}}+\mathrm{e}
\end{aligned}
$$

Description: INF: Inflation (\%), tax: taxes (bn Rupiah), GOV: Government expenditure (billion Rupiah), GDP: Gross domestic product (US \$), INV: Investment (US \$), SBK: Interest 
rate of credit (\%), JUB: Amount of money supply (billion rupiahs), exchange rate: Currency exchange rate (US \$), GDP: Gross domestic product (US \$), E: Error term, $\beta$ : regression coefficient, $\alpha$ : constant P: Optimal lag length, I: State of observation (7 countries) T: The amount of time (8 years, 2010 SD 2017).

\section{Results and Discussion}

Data analysis panel results of ARDL mentions

Table 1. Output Panel ARDL

\begin{tabular}{lllll}
\hline \hline \multicolumn{5}{l}{ Short Run Equation } \\
\hline \hline COINTEQ01 & -0.912921 & 0.161860 & -5.640175 & 0.0000 \\
D(INF(-1) & 0.026479 & 0.071777 & 0.368905 & 0.7136 \\
D(TAX) & -1.062384 & 1.780055 & -0.596826 & 0.5530 \\
D(GOV) & 0.062269 & 0.176649 & 0.352500 & 0.7258 \\
D(LNPDB) & 29.28328 & 7.699262 & 3.803387 & 0.5854 \\
(INV) & -0.918738 & 0.890686 & -1.031495 & 0.3067 \\
( (LNKURS) & 25.87371 & 7.122522 & 3.632661 & 0.8406 \\
D(SBK) & 0.017962 & 0.712048 & 0.025226 & 0.9635 \\
D(JUB) & -0.044712 & 0.031078 & -1.438688 & 0.0257 \\
C & 11.64596 & 2.993129 & 3.890899 & 0.0003 \\
\hline \hline
\end{tabular}

Testing over the ARDL panel should have a significant level negative slope basis. The value is negative $(-0.78)$ in the direction of a significant probability $(0.01<0.05)$. The overall outcome is known that a significant long-term influence on inflation in emerging Muslim countries is government expenditure, interest rates, and the amount of money supply. Then in the short-term amount of money supply that affects the stability of inflation. Leading indicators of the effectiveness of variables in the stability control of emerging market Muslim countries are the amount of money supply (Indonesia, Bangladesh, Malaysia, Pakistan and UAE, Saudi Arabia, Egypt and Turkey) judging by the stability of short-run and long-run, Where the variable amount of money circulating in the long term as well as short significant control of economic stability. The leading indicator of the country's effectiveness in the stability control of Muslim emerging market countries is namely Indonesia, Bangladesh (tax, government expenditure, amount of money supply, interest rates of credit and amount of money supply) and Malaysia (tax, Government expenditure, investment and the amount of money supply). Other countries e.g. UAE and Saudi Arabia's economic stability control are conducted by taxes, investments and the amount of money supply, whereas Egypt and Turkey are made through the amount of money supply. In panel, apparently the amount of money supply can be a leading indicator for the control of countries Indonesia, Bangladesh, Malaysia, Pakistan, UAE, Saudi Arabia, Egypt, and Turkey. Here's a summary of ARDL Panel results table: 
Table 2. Summary of ARDL Panel

\begin{tabular}{|c|c|c|c|c|c|c|c|c|c|c|}
\hline & $\begin{array}{l}\text { Indon } \\
\text { esia }\end{array}$ & $\begin{array}{c}\text { Bangla } \\
\text { desh }\end{array}$ & $\begin{array}{c}\text { Mala } \\
\text { ysia }\end{array}$ & $\begin{array}{c}\text { Pakis } \\
\text { tan }\end{array}$ & UEA & $\begin{array}{l}\text { Arab } \\
\text { Saudi }\end{array}$ & Mesir & $\begin{array}{l}\text { Tur } \\
\text { key }\end{array}$ & $\begin{array}{l}\text { Short } \\
\text { Run }\end{array}$ & $\begin{array}{l}\text { Long } \\
\text { Run }\end{array}$ \\
\hline Pajak & I & I & I & I & $\mathrm{O}$ & I & $\mathrm{O}$ & $\mathrm{O}$ & $\mathrm{O}$ & $\mathrm{O}$ \\
\hline GOV & I & I & I & I & $\mathrm{O}$ & $\mathrm{O}$ & $\mathrm{O}$ & $\mathrm{O}$ & $\mathrm{O}$ & I \\
\hline PDB & $\mathrm{O}$ & $\mathrm{O}$ & $\mathrm{O}$ & $\mathrm{O}$ & $\mathrm{O}$ & $\mathrm{O}$ & $\mathrm{O}$ & $\mathrm{O}$ & I & $\mathrm{O}$ \\
\hline Investasi & $\mathrm{O}$ & $\mathrm{O}$ & I & $\mathrm{O}$ & I & $\mathrm{O}$ & $\mathrm{O}$ & $\mathrm{O}$ & $\mathrm{O}$ & $\mathrm{O}$ \\
\hline Kurs & $\mathrm{O}$ & $\mathrm{O}$ & $\mathrm{O}$ & $\mathrm{O}$ & $\mathrm{O}$ & $\mathrm{O}$ & $\mathrm{O}$ & $\mathrm{O}$ & I & $\mathrm{O}$ \\
\hline Bungakred & I & I & $\mathrm{O}$ & I & $\mathrm{O}$ & $\mathrm{O}$ & $\mathrm{O}$ & $\mathrm{O}$ & $\mathrm{O}$ & I \\
\hline JUB & I & I & I & I & I & I & I & I & I & I \\
\hline Inflasi & $\mathrm{O}$ & $\mathrm{O}$ & $\mathrm{O}$ & $\mathrm{O}$ & $\mathrm{O}$ & $\mathrm{O}$ & $\mathrm{O}$ & $\mathrm{O}$ & $\mathrm{O}$ & $\mathrm{O}$ \\
\hline
\end{tabular}

Source: Data Processed, 2019

Here's a summary of the long-term stability of Muslim emerging markets

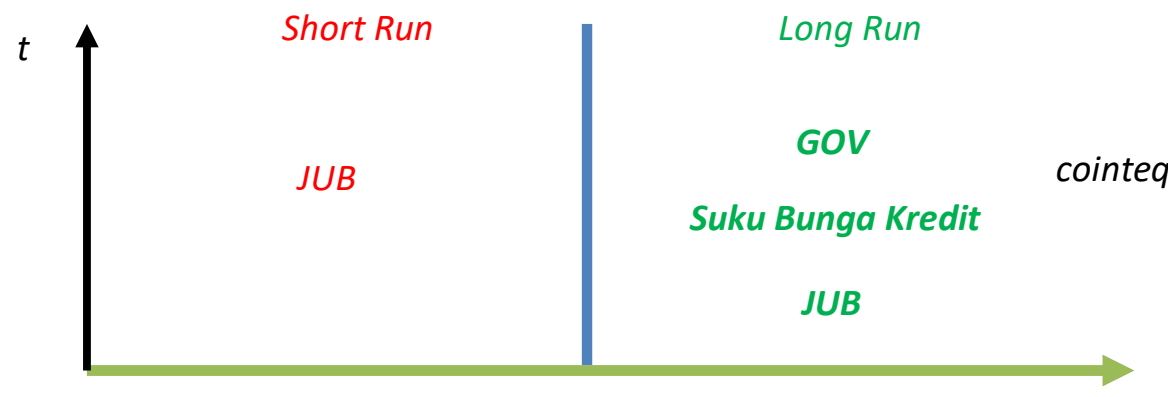

Fig 3. predicted the economic resilience of Muslim countries Emerging Market

Leading indicators of countries in the control of emerging market Muslims, namely Indonesia, Bangladesh (tax, government expenditure, money supply, interest rates of credit and money supply) and Malaysia (tax, government expenditure, investment and money supply Countries: UAE and Saudi Arabia's economic stability control is conducted by taxes, investments, and money supply, whereas Egypt and Turkey are conducted through money supply. The Indonesian state is still strong in controlling price stability through the exchange rate stability. Bangladesh is still strong in controlling price stability through the durability of the money supply. Malaysia is still strong in controlling price stability [19]. The development of money supply as leading indicators of economic resilience in Indonesia, Bangladesh, Malaysia, Pakistan and UAE, Saudi Arabia, Turkey. Leading indicators of the stability control of emerging market countries are money supply (Indonesia, Bangladesh, Malaysia, Pakistan and UAE, Saudi Arabia, Turkey) [20]. Nwaobi [21] states money supply affects fundamental resilience. Mgadmi [22], money circulating positively on economic fundamentals then Hussain [15] supported Mgadmi [22] and Forhad [23]. The monetary policy approaches price affects inflation through interest rates and exchange rate channels [19,24,25]. 


\section{Conclusion}

The panel turns out to be the leading indicator for controlling the country of Indonesia, Bangladesh, Malaysia, Pakistan, and UAE, Saudi Arabia, Turkey. And the position is stable in the short-run and long run. The leading indicator of the effectiveness of the variables in the stability control of emerging market Muslims is the investment seen from the stability of the short-run and long-run, where the variable amount of money circulating in the long and short term is significant in controlling economic stability.

\section{References}

[1] Natsir, M. The role of the interest rate pathway in the monetary policy transmission mechanism in Indonesia. Lecturer of Fe \& Program of Unhalu Kendari. Thesis. Unpublished (2014).

[2] Onyeiwu. C. Monetary Policy And Economic Growth Of Nigeria. Journal Of Economics And Sustainable Development. Vol.3, No.7, (2012).

[3] Surjaningsih, Dewati, W., N., dan Chawwa, T. Revisiting Transmisi Kebijakan Moneter: Pendekatan VAR dan Panel Data. Laporan Hasil Penelitian Bank Indonesia, (19) (2015).

[4] Stock, J. H., dan Watson, M. W. Forecasting Using Principal Components from a Large Number Predictors. Journal of the American Statistical Association. Vol. 97 No 460 (2011).

[5] Odo, A.C., Odiony, J.K., and Ojike, R.O. Inflation Dynamics In Nigeria: Implications For Monetary Policy Response. Journal of Economics and Sustainable Vol.7, No.8, (2016).

[6] Hasibuan, Saida dan Pratomo, Aria, Wahyu. The mechanism of transmission of monetary policy through the SBI rate as the operational target of monetary and macroeconomic variables of Indonesia. Jurnal Ekonomi dan Keuangan. Vol.1 No.12 (2012).

[7] Hai, B.V., and Trang, T.T.M. The Transmission Mechanism Of Monetary Policy In Vietnam: A VAR Approach. The Graduate Institute of International and Development Studies Geneva, Working Paper N IHEIDWP15-2015 (2015).

[8] Oliner, S.D. dan Rudebusch, G. D. Is There a Broad Credit Channel for Monetary Policy? FRBSF Economic Review (1) (2014).

[9] Wimanda, R.E., Maryaningsih, N., Nurliana, L, and Satyanugroho, R. Evaluation transmission of Bank Indonesia policy mix. Working Paper WP/03/2014, Bank Indonesia (2014).

[10] Soares, R. Assessing Monetary Policy in the Euro Area: a Factor-Augmented VAR Approach. Banco de Portugal Working Paper, (11) (2011).

[11] Oguanobi, C.R., Akamobi, A.A., and Agu, C.C. Cross-Border Transmission Of Interest Rate Shocks A VAR Analysis Of The Nigerian Economy. Journal of Economics and Sustainable Development Vol.5, No.7, (2014).

[12] Ginting, Mulianta Ari. Effect of exchange rate on exports in Indonesia. Trade Research Scientific Bulletin. Vol.7 No.1 (2015). 
[13] Sheefeni, J.P., and Kalikeka. M. Interest Rate Channel And Monetary Transmission In Zambia. Journal Of Emerging Issues In Economics, Finance And Banking (Jeiefb) Volume:2 No.6, (2013).

[14] Sitaresmi, N. Analisis Pengaruh Guncangan Kurs Yen Dan Usd Terhadap Rupiah Dalam Mekanisme Transmisi Kebijakan Moneter Melalui Jalur Nilai Tukar Di Indonesia. Departemen Ilmu Ekonomi Institute Pertanian Bogor (2006).

[15] Hussain, Z. A.N. The Lags In Effect Of Monetary Policy: A Case Study Of Pakistan. Pakistan Economic And Social Review Volume 52, No. 1 (Summer 2014), Pp. 1-14 (2014).

[16] Hsing. Y. Monetary Policy Transmission And Bank Lending In China And Policy Implications. Journal Of Chinese Economics, 2014 Vol. 2, No. 1, Pp 1-9 (2015).

[17] Shenglin, N.Y.G., and Ben. Should Practice Simple Central Banking To Help Rmb Internationalization. Journal Of Chinese Economics, 2016 Vol. 4. No. 2. Pp. 35-46 (Online) (2016).

[18] Rosoiu (2015), A. Emerging Markets Queries Monetary Policy And Time-Varying Parameter Vector Autoregression Model. The Bucharest University of Economic Studies, Procedia Economics, and Finance 32, 496 - 502 (2015).

[19] Nguyen, Boateng. "The Impact Of Excess Reserves Beyond Precautionary Levels On Bank Lending Channels In China," Journal Of International Financial Markets, Institutions And Money 26, 358-377 (2013).

[20] Nwaobi, Godwin Chukwudum. The Balance of Payments as a Monetary Phenomenon: An Econometric Case Study of Nigeria". Papers by JEL Classification. Pages 1-34 (2014).

[21] Nwaobi, Godwin Chukwudum. The Balance of Payments as a Monetary Phenomenon: An Econometric Case Study of Nigeria". Papers by JEL Classification. Pages 1-34 (2003).

[22] Mgadmi, N., and Chrigui, Z. Monetary Policy's Transmission Channels In Tunisia: SVAR Model Validation. Journal of Business and Management Research, 8 (2015) 189 200 p-ISSN: 2356-5756 / e-ISSN: 2356-5764 (2017).

[23] Forhad, A.R., Homaifar, G.A., and Salimullah, A.S.M. Monetary Policy Transmission Effect On The Realsector Of The Bangladesh Economy: An Svar Approach. Economia Internazionale / International Economics Volume 70, Issue 1 - February, 25-46 (2017).

[24] Vymyatnina.Y. Monetary Policy Transmission And Bank Of Russia Monetary Policy. Department of Economics European University at St Petersburg, Working paper Ec02/05 (2011).

[25] Havránek, T., And Rusnák, M. Transmission Lags Of Monetary Policy: A MetaAnalysis. Czech National Bank, Working Paper Series 10 (2012). 